Towards the theory of decoupling : Degrees of decoupling in the EU and the case of road traffic in Finland between 1970 and 2001

Tapio, P.

Elsevier 2005

Tapio, P. 2005. Towards the theory of decoupling: Degrees of decoupling in the EU and the case of road traffic in Finland between 1970 and 2001. Transport Policy 12(2):137-151 (2005)

http://hdl.handle.net/1975/275

Downloaded from Helda, University of Helsinki institutional repository.

This is an electronic reprint of the original article.

This reprint may differ from the original in pagination and typographic detail.

Please cite the original version. 


\title{
Towards a theory of decoupling: degrees of decoupling in the EU and the case of road traffic in Finland between 1970 and 2001
}

\author{
Petri Tapio* \\ Finland Futures Research Centre, Telework address Kurupolku 1 E 23, Fin-01280 Vantaa, Finland
}

Received 3 April 2003; revised 17 December 2004; accepted 7 January 2005

\begin{abstract}
Traditionally, the transport literature reflects the view that traffic volumes, road traffic volumes in particular, are coupled with Gross Domestic Product (GDP). Recently published literature also argues that the carbon dioxide $\left(\mathrm{CO}_{2}\right)$ emissions from transport, passenger cars in particular, have not shown any decoupling from transport volumes for some years. This article presents a theoretical framework for decoupling, defining the difference between decoupling, coupling and negative decoupling. These are further broken down to weak, strong and expansive/recessive degrees of decoupling, laying emphasis on the absolute increase or decrease of the variables. The result section presents data of the development of the relationships between GDP, traffic volumes and $\mathrm{CO}_{2}$ emissions from transport in the EU15 countries between 1970 and 2001, including the special case of Finnish road traffic. The aggregate EU15 data show a change from expansive negative decoupling to expansive coupling regarding passenger transport, and from weak decoupling to expansive negative decoupling regarding freight transport. Weak decoupling of transport $\mathrm{CO}_{2}$ emissions from GDP could also be observed. Weak decoupling of all the three aspects (freight, passenger and $\mathrm{CO}_{2}$ ) could be seen in the UK, Sweden and Finland in the 1990s. In Finland, the statistics show weak decoupling of GDP from road traffic volume and strong decoupling of road traffic volume and $\mathrm{CO}_{2}$ emissions from road traffic between 1990 and 2001. Four hypothetical explanations of the Finnish phenomenon are put forward in this article: policy towards sustainable mobility, green urban lifestyle, increasing income differences, and statistical misinterpretation. Each explanation is backed up with some quantitative evidence in observable trends in Finland during the 1990 s.
\end{abstract}

(C) 2005 Elsevier Ltd. All rights reserved.

Keywords: Decoupling; Gross domestic product; Transport volume; Carbon dioxide emissions; European union; Finland

\section{The discourse of no-decoupling}

Traditionally, the transport literature reflects the view that traffic volumes and especially road traffic volumes are strongly connected to Gross Domestic Product (GDP). Recently published literature has increasingly shown that there has not been any reduction in the carbon dioxide $\left(\mathrm{CO}_{2}\right)$ intensity of transport, especially in road traffic

\footnotetext{
* Tel.: +358 95613 6742; fax: +35822330755.

E-mail address: petri.tapio@tukkk.fi.

$U R L:$ www.tukkk.fi/tutu/engltapio.htm.
}

0967-070X/\$ - see front matter (C) 2005 Elsevier Ltd. All rights reserved. doi:10.1016/j.tranpol.2005.01.001
(Banister and Stead, 2002). However, the period under examination differs between the studies. For example, a study commissioned by the European Conference of Ministers of Transport (ECMT) concluded that the seven largest car manufacturing countries of Europe did not show any improvement in the fuel efficiency of passenger cars between 1985 and 1995 (Lampinen, 1998; IPCC, 2001). The International Energy Agency (IEA, 2000) detected a similar stagnation in Japan and the USA. Van den Brink and Van Wee (2001) reported that the fuel efficiency improvement levelled off in the Netherlands between 1990 and 1997, resulting in the same conclusions concerning $\mathrm{CO}_{2}$ emissions. In Finland, similar results are displayed between 1978 and 1996 (Tapio, 2002a,b). 
Several propositions have been put forward in order to explain the phenomenon. So far, nobody seems to have suggested that technical development would have stopped altogether. Rather, it has been argued that the weight and engine power of new cars have increased and, thus, nullified the positive technical development. The increase of air conditioning and electric equipment in the new cars have also been stated as reasons (Van den Brink and Van Wee, 2001). These explanations are rather technical and lead to the societal question: why is this happening?

The most popular social explanation seems to be the consumers demand for bigger and more powerful cars (Acutt and Dodgson, 1998, 28-29; Van den Brink and Van Wee, 2001; Tapio, 2002b). As has been shown by empirical research, for a significant segment of consumers the private car seems to hold status values which cannot be reduced to the rational need to move from point A to point B (Jensen, 1999; Mokhtarian and Salomon, 2001; Steg et al., 2001; Hiscock et al., 2002).

Explanations are less frequently searched for from the supplier's side. However, a Delphi study on expert views in Finland resulted in opinions that the car manufacturers and salesmen would in fact promote larger cars (Tapio, 2002b; see also Tengström, 1999). On the other hand, the European car industry organisation (ACEA) made a voluntary agreement with the ECMT that they will drop the average carbon dioxide $\left(\mathrm{CO}_{2}\right)$ emissions of new cars from $187 \mathrm{~g} / \mathrm{km}$ in 1995 to $140 \mathrm{~g} / \mathrm{km}$ by 2008 (CEGTE, 2000). This reduction can also be expressed as a decline of average gasoline consumption from 7.2 to $5.81 / 100 \mathrm{~km}$ (Ministry of Transport and Communications, 1999).

The agreement has been overshadowed by increasing traffic volumes, following the increasing GDP. There was little, if any, success in the much discussed decoupling of the trends between 1985 and 1995 (Peake, 1994; Lampinen, 1998; Nijkamp et al., 1998; Banister et al., 2000; IPCC, 2001; Stead, 2001; Banister and Stead, 2002).

This article presents data of the developments of relationships between GDP, road traffic volume and $\mathrm{CO}_{2}$ emissions from road traffic in Finland between 1970 and 2001. The Finnish case is framed with comparisons to all of the fifteen European Union (EU15) countries. The definition of decoupling is presented in Section 2.1 and further elaborated into various degrees of decoupling in Section 2.2. Section 3 presents the results and suggests that at least a weak signal of decoupling can be detected regarding the Finnish data in the 1990s. A discussion of the factors behind the development in Finland and the pitfalls of the analysis are given in Section 4.

\section{A theoretical framework on decoupling}

\subsection{The general definition of decoupling}

Decoupling of transport volume growth from economic growth can be expressed as elasticity values under 1.0, where the percentage change of transport volume is divided by the percentage change of GDP in a given time period

GDP elasticity of transport $=\% \Delta \mathrm{VOL} / \% \Delta \mathrm{GDP}$

Here, transport volume can be measured as passenger transport (passenger $\mathrm{km}$ ) or freight transport (tonne $\mathrm{km}$ ). It may also be expressed by specific traffic modes. Regarding the major modes of moving on the road, it may be expressed as vehicle $\mathrm{km}$, a useful measure for transport planning. It is important to keep in mind which aspect of transport is actually measured. The time period used should comprise several, say, 5-10 years, as there is supposedly a lag in the changes of economic growth rate to consumption. The more general the trends observed, the longer the time period should be. In this article the elasticities are reported by decade.

Decoupling of transport $\mathrm{CO}_{2}$ emissions from transport volume can be measured as in (2) below:

Transport elasticity of $\mathrm{CO}_{2}$ emissions

$=\% \Delta \mathrm{CO}_{2} / \% \Delta \mathrm{VOL}$

The product of (1) and (2) gives:

GDP elasticity of transport $\mathrm{CO}_{2}=\% \Delta \mathrm{CO}_{2} / \% \Delta \mathrm{GDP}$

A number of different concepts have been used to express the different aspects of decoupling (Vehmas et al., 2003). For example, decoupling measured by Eq. (1) is also refered to as immaterialisation, qualitative growth and structural change (Jänicke, 1988; Tapio, 2002a). Decoupling measured by Eq. (2) has been called also dematerialisation, eco-efficiency and simply technical development (Hinterberger and Schmidt-Bleek, 1999; de Bruyn, 2002; Tapio, 2002a). Decoupling measured by Eq. (3) has been termed as decarbonisation, de-linking and different factor concepts (de Bruyn et al., 1998; Hinterberger and Schmidt-Bleek, 1999; Schmidt-Bleek, 2000). Sometimes de-linking is used as a wider synonym for decoupling, regardless of the concept's exact definition (see Vehmas et al., 2003).

\subsection{Redefining decoupling}

The discourse of decoupling economic growth from transport volume growth relates to the more general discourse of delinking economic growth from increasing environmental problems. On one side of the discourse, it is claimed that in the early phases of economic development, growth is achieved with increasing environmental problems, that is, pollution and exploitation of the resources. As the development continues, the economy will become less harmful for the environment due to investments in technological and economic efficiency. When using economic output per capita as the $x$-axis and environmental harm as the $y$-axis, an inverted $U$-curve 


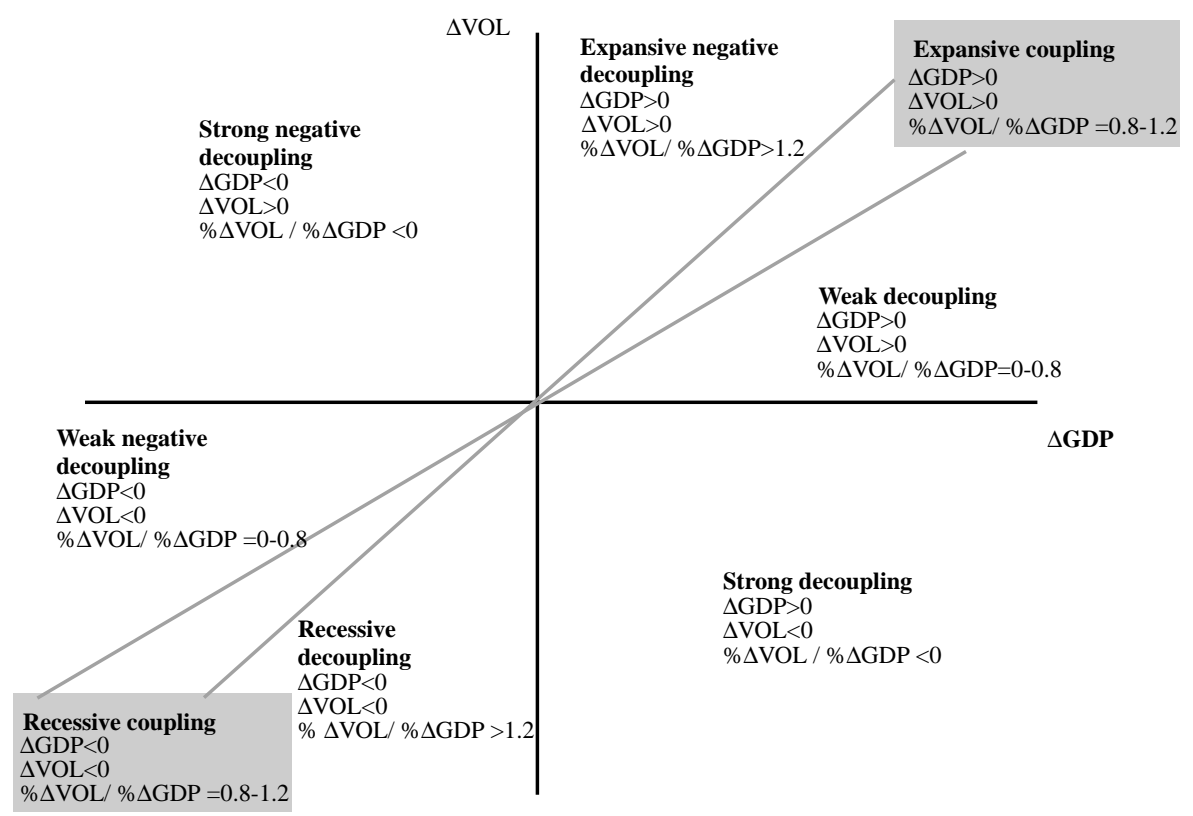

Fig. 1. The degrees of coupling and decoupling of transport volume growth ( $\Delta$ VOL) from economic growth $(\Delta \mathrm{GDP})$ (modified from Vehmas et al., 2003, 31).

will appear. This is often called the environmental Kuznets curve (EKC) hypothesis. ${ }^{1}$ (Arrow et al., 1995; de Bruyn et al., 1998; de Bruyn, 2002.)

A number of empirical studies have been conducted in order to verify or reject the EKC hypothesis. The results of the studies vary strongly by country, time frame and the set of environmental indicators used (Arrow et al., 1995; de Bruyn et al., 1998; Kaivo-oja and Haukioja, 2002; de Bruyn, 2002; Canas et al., 2003; Focacci, 2003; Kriström and Lundgren, 2005). Some studies have suggested that in many western industrial countries, regarding total material flows and carbon dioxide $\left(\mathrm{CO}_{2}\right)$ emissions, the hypothesis did hold for the period from 1970 to 1985 , but not after that (Seppälä et al., 2001; de Bruyn, 2002). EKC described the development of sulphur emissions (measured in $\mathrm{SO}_{2}$ ) rather well, but it was less successful in describing the development of nitrogen oxide emissions $\left(\mathrm{NO}_{x}\right)$, and the least successful in describing the development of the $\mathrm{CO}_{2}$ emissions in the UK, USA, Western Germany, Netherlands and Finland (de Bruyn et al., 1998; Kaivo-oja and Haukioja, 2002). According to these studies the inverted $U$-curve of $\mathrm{CO}_{2}$ emissions has rather converted to an $N$-curve. As the inverted $U$-curve represents delinking or dematerialisation, the last phase of the $N$-curve has been

\footnotetext{
${ }^{1}$ The EKC concept originates from the economist Simon Kuznets (1955) who found first constant and then decreasing income differences in German, UK and US data from the late 19th century to the 1940s. He also put forward a hypothesis, that in the early phases of industrialisation, income differences would have increased. Later this hypothesis has been labelled as the 'inverted $U$ curve' (e.g. Todaro, 1994, 154) which has thereafter been adopted in environmental analyses.
}

described by the term relinking or rematerialisation (de Bruyn, 2002; Vehmas et al., 2003). ${ }^{2}$

Based on a review on the issue, Vehmas et al. (2003, 24-32) have constructed a comprehensive framework of the different aspects of decoupling. They use the concept of de-linking, reflecting the terminology used in environmental economics. In this article the term decoupling is applied as it is used more often in transport discourse. Vehmas et al. also use the concept of re-linking, which here is termed negative decoupling. There has not been much evidence of decoupling in transport nor transport $\mathrm{CO}_{2}$ emissions, hence the concept of re-coupling would perhaps give a misleading connotation to the $N$ curve.

According to the framework, eight logical possibilities can be distinguished (Fig. 1). The growth rate of GDP and an indicator of traffic volume (see Eq. (2) above) can be coupled, decoupled or negatively decoupled. The same framework may be used for the analysis of Eqs (1) and (3) as well. In order not to overinterpret slight changes as significant, a $\pm 20 \%$ variation of the elasticity values around 1.0 are here still regarded as coupling. Thus coupling is defined as elasticity values of $0.8 \ldots 1.2$. On the other hand, the growth of the variables per se can be positive or negative, expressed as expansive coupling and recessive coupling.

Decoupling can be further divided to three subcategories: in weak decoupling, GDP and transport volume both increase (and $0<$ elasticity $<0.8$ ), strong decoupling occurs when GDP grows and transport volume decreases

\footnotetext{
${ }^{2}$ One must keep in mind that the EKC hypothesis focuses on GDP per capita values and hence is different from the concept of decoupling which is usually related to the aggregate GDP of the total economy.
} 
(and elasticity $<0$ ) and recessive decoupling when GDP and transport volume both decrease (and elasticity $>1.2$ ).

Similarly, negative decoupling includes three subcategories: in expansive negative decoupling GDP and transport volume both increase (elasticity $>1.2$ ), in strong negative decoupling GDP decreases and traffic volume increases (elasticity $<0$ ) and weak negative decoupling occurs when both variables are decreasing $(0<$ elasticity $<0.8$ )

Negative GDP growth has been very rare in the EU15 countries for a period of several years, and some of the logical possibilities may seem unrealistic from the western point of view, such as strong negative decoupling where GDP declines and traffic volume increases. However, there seems to be many countries in the Eastern Europe where this probably happened in the 1990s after the collapse of the centrally planned economy and the simultaneous release of the previously latent demand resulting in a high growth in passenger car density (TERM, 2002, 32; Eurostat, 2003).

\section{Statistical data on decoupling in the EU}

The development of the EU15 countries from 1970 to 2001 are interpreted in the light of the theoretical framework in Section 3.1. Some caution is required regarding the data. Passenger traffic and freight transport volume data are from Eurostat Energy \& Transport in Figures $(1999,2002,2003)$ statistics, GDP and $\mathrm{CO}_{2}$ emissions data are from IEA (2003). GDP is measured in purchasing power parities $\left(\mathrm{GDP}_{\mathrm{ppp}}\right)$ in order to eliminate the effect of currency fluctuations. Also, the GDP data measured in market exchange rates $\left(\mathrm{GDP}_{\text {mer }}\right)$ in real terms were used in comparison. However, the changes in growth rates of $\mathrm{GDP}_{\mathrm{ppp}}$ and $\mathrm{GDP}_{\text {mer }}$ between 1970 and 2001 were less than $0.01 \%$ units by decade in all of the EU15 countries according to the IEA data, thus the comparison is not included in this article. This seems to present suspiciously small changes in currency fluctuations as IEA reports differences of $0.5 \%$ units between 1970 and 1980;0.1\% units between 1980 and 1990; and $0.2 \%$ units between 1990 and 2000 in the growth rates of GDP $\mathrm{ppp}_{\text {and }}$ GDP $\mathrm{P}_{\text {mer }}$ for the total EU15 area. When using Eurostat GDP data for the total area of EU15, some differences were found.

The quality of Eurostat freight data is not very good for measuring decoupling as there are many changes in the statistics. Although the accuracy will probably become better due to the changes, the analyses of changes in temporal trends become difficult, if the effects of the changes are not updated backwards to earlier data. The problem of discontinuity is present for the road haulage data of Denmark, Germany, Portugal, Spain and the UK; rail freight in Germany and Austria; pipeline transport in Germany and domestic sea freight in the UK. There are changes as high as $20 \%$ within a year and it is difficult to interpret which part of the change is due to real changes and which part due to changes in statistics. Therefore, no elaborations of the freight transport data have been made. The GDP elasticity values of freight transport are probably a little too high for Denmark and Spain for the period between 1990 and 2000. To ameliorate the discontinuity effect, the period between 1991 and 2001 in the Portuguese and German freight data corresponds to the period between 1990 and 2000 in the other countries.

The intra-EU sea transport data (that is, other waterborne transport than domestic sea and inland waterways) are presented by country in the reference only from 1970 to 1996, although estimates for the total EU15 area have been presented also from 1997 to 2001 (Eurostat, 2003). The separate countries' shares of the EU total have changed through the decades partly due to changes in statistics, thus no good estimates for temporal per country comparisons can be provided. The results may be biased, as the share of intraEU sea transport of total freight transport has been relatively high according to Eurostat (86\% of sea transport and 35\% of total freight transport in 2001), having growth rates almost similar to that of road freight. Making estimates of the shares by country for the period between 1997 and 2001 would rather produce circular reasoning instead of analysis of decoupling. This is why only the total area of EU15 is analysed considering the decoupling of freight transport, intra-EU sea transport included. For the comparisons by country, intra-EU sea transport is excluded.

Another pitfall emerges from the incomparable methods used in obtaining the data, which makes it difficult to compare the volumes of different countries. For example, Eurostat freight transport data regarding Sweden and the UK are measured for national operators only. However, as long as the different methods do not affect a bias in the temporal growth rate, this problem is less severe in defining whether decoupling occurs or not.

Passenger transport data contains fewer changes according to Eurostat statistics. The only elaboration of data in the analysis concerns the last decade's data of Spain, where the time period between 1991 and 2001 is used due to a significant change of the statistics in 1990/91, showing an apparent rise of $19 \%$ in passenger car traffic in one year. The German data for bus and coach transport includes changes between the years 1980/1990 and 1990/91, but it is unclear how the changes should be adjusted. Danish bus and coach traffic statistics were changed in 1997/98, which probably results in a little too low GDP elasticity value of passenger transport between 1990 and 2000.

The Eurostat (2003) statistics include air traffic data from 1990 to 2001. The values for the years of 1970 and 1980 were estimated assuming a constant relative growth rate in the air transport by each country. This varied from the $42 \%$ rise by decade in Sweden to the $135 \%$ rise by decade in the Netherlands (80\% in EU15 total). As the modal share of air traffic was small before 1990 (4,0\% of total EU15 motorised passenger traffic), the assumption does not affect the results severely in comparison to the changes in the statistics 
considering road traffic. Walking and cycling are excluded from the analysis, as the reference had statistics only for the period between 1992 and 2001 and it is questionable whether any conclusions of the past can be derived from the data. Also maritime passenger traffic is excluded from the analysis due to lack of data.

The case of Finnish road traffic is the focus of Section 3.2, where $\mathrm{CO}_{2}$ data are from the LIPASTO database of VTT Technical Research Centre of Finland (Mäkelä, 2002), road traffic volume data measured in vehicle $\mathrm{km}$ from the Finnish Road Administration (FinnRA, 2002) and GDP data from Statistics Finland (2002a). The $\mathrm{CO}_{2}$ emission data from IEA and VTT are not directly comparable, as VTT uses a more sophisticated methodology than IEA, who rest on the sectoral calculations recommended by the Intergovernmental Panel on Climate Change (IPCC) (see IEA, 2003; Mäkelä, 2002 for details). The IEA data does not include emissions from international aviation and waterborne bunkers, whereas the VTT data does.

VTT provides $\mathrm{CO}_{2}$ data only from 1980 on. The data for the period between 1970 and 1979 were calculated using diesel and petrol sales statistics between 1970 and 1985 . There was no difference in the growth rate between 1980 and 1985, but a slight systematic correction was needed in order to make the values comparable.

FinnRA changed its statistics by uplifting the estimate of street traffic by some 30\% in 1992. This change was updated backwards for the period from 1970 to 1991 assuming that the percentual share of additional street traffic was constant throughout the period. Another change in 1998 was considered so small that no updating of the earlier data was considered necessary. The elaborations of the Finnish road traffic and $\mathrm{CO}_{2}$ data were confirmed by consulting the employees in charge at FinnRA, Ministry of Transport and VTT.

\subsection{Decoupling in the EU15 countries}

According to the Eurostat and IEA statistics, passenger transport volume followed the growth of GDP in the 1970s, exceeded GDP growth in the 1980s, and grew a little slower than GDP in the 1990s in the EU15 countries as a whole. The development in the 1970s presents expansive coupling (elasticity of 1.08), in the 1980s expansive negative decoupling (elasticity of 1.22), and again in the 1990s expansive coupling (elasticity of 0.85) (Fig. 2). The drop of the GDP elasticity of passenger traffic in the 1990s may be a weak signal of a more significant change in the current decade.

Freight transport volume, in contrast, followed a different pattern (Fig. 2): It also followed GDP growth in the 1970s, but then the growth rate declined in the 1980s only to increase to a clearly higher growth rate than the GDP in the 1990s. The development in the 1970s presents positive coupling, in the 1980s weak decoupling, and in the 1990s expansive negative decoupling. Two elasticity values can be

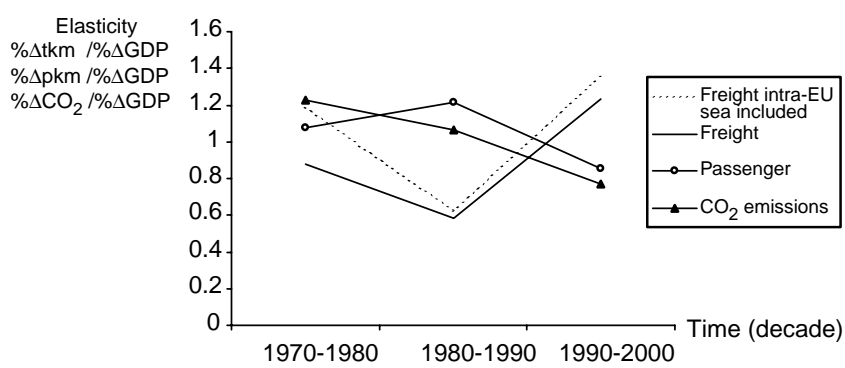

Fig. 2. $\mathrm{GDP}_{\mathrm{ppp}}$ elasticities of passenger traffic volume (pkm), freight transport volume (tn $\mathrm{km}$ ) and transport $\mathrm{CO}_{2}$ emissions in the EU15 countries 1970-2000 by decade (IEA, 2003; Eurostat, 2003).

calculated for each decade, one focusing on national freight transport only, and the other including also intra-EU sea transport; the values were 0.88 and 1.19 in the 1970 s; 0.59 and 0.62 in the 1980s; 1.23 and 1.37 in the 1990s, respectively. The results imply that the globalisation of the economy from the late 1980s on and the enlargement of the EU in mid-1990s in fact increased the material throughput of the economy.

According to the IEA data, the development of $\mathrm{CO}_{2}$ emissions of transport in the EU15 countries is not totally in line with the no-decoupling discourse reviewed in the introduction (Fig. 2). The lack of data on potentially growing international air and maritime transport emissions may partly explain the difference. The $\mathrm{CO}_{2}$ emissions presented expansive negative decoupling with GDP growth in 1970s, expansive coupling in the 1980 s and weak decoupling in the 1990s, and the elasticity values were $1.23,1.07$ and 0.77 , respectively. The EKC hypothesis did not hold, however, as it would have required strong decoupling with elasticity values below zero. In order to be able to measure elasticity values between transport volumes and $\mathrm{CO}_{2}$ emissions, the data should be more consistent, including mode specific emissions, which were not available in the IEA database.

As individual countries are observed, the picture shows many contradicting trends in degrees of decoupling within the EU15, especially in the 1990s. Fig. 3 presents the GDP elasticity values of passenger transport in each EU15 country by decade. The countries are in a descending order based on the values in 1990s. Fig. 4, in turn, places the different countries into the theoretical framework. It may be concluded that, in the 1990s, weak decoupling occurred in seven countries: the UK, Germany, Finland, Luxembourg, Netherlands, Austria and Sweden. Expansive coupling could be distinguished only in Ireland, Denmark, France and Belgium. A cluster of countries experienced expansive negative decoupling in the 1990s: Italy, Spain, Portugal and Greece. Of these four, Italy and Greece had a decrease compared to the elasticity values of the 1980s. Spain is a special case where mobility growth was based not only on car traffic growth but also on bus and coach performance. 


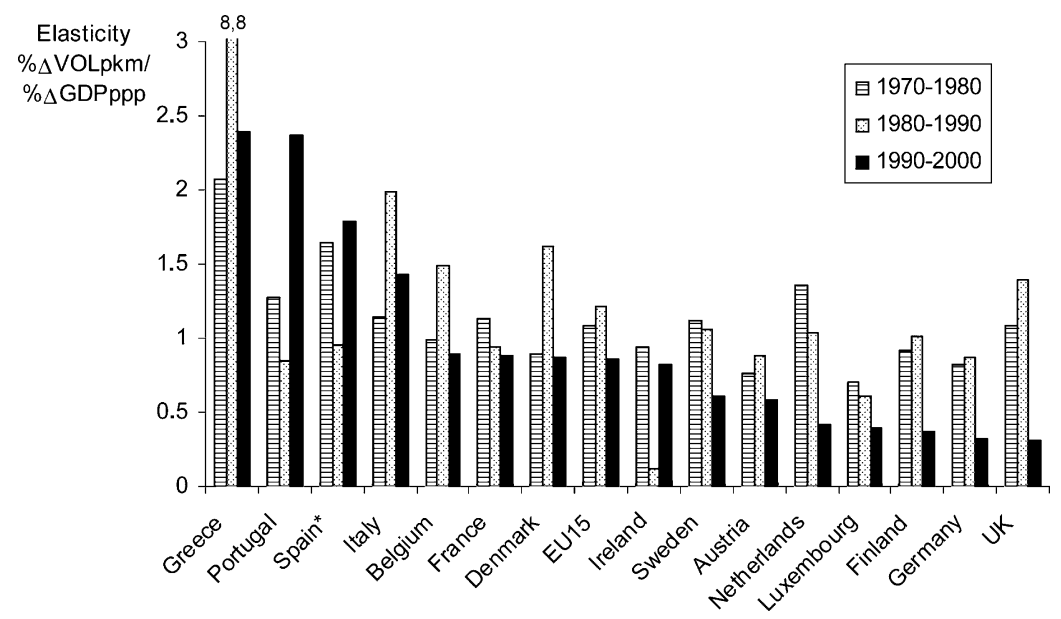

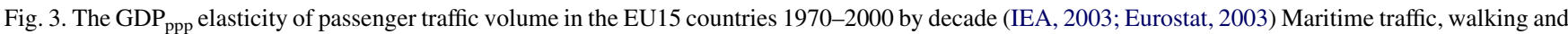
cycling excluded. Intra-EU and domestic flights are included for 1990 and 2000 and air traffic volume is extrapolated backwards for 1980 and 1970 assuming constant relative growth by country by decade. *The last decade of Spain contains the years 1991-2001.

Fig. 5 presents the GDP elasticities of freight transport per country by decade in the EU15 area between 1970 and 2000. The order of the countries varied a great deal during the period and the picture was dispersed in the 1990s (see also Fig. 6). Although the EU15 area as a whole turned to an era of expansive negative decoupling in the 1990s, five countries performed weak decoupling: Finland, Sweden, the UK, Ireland and Luxembourg, the Netherlands, with the elasticity value of 0.82 , being on the borderline of the definition used in this paper. Surprisingly enough, expansive coupling was present only in Netherlands and Portugal in the 1990s.
All the other EU15 countries experienced expansive negative decoupling in the 1990s. The rise in elasticity values was exceptionally high in Germany, Austria and France as they have a central position in the map of Europe and therefore had a large growth of transit traffic.

Finally, the focus is on the decoupling of transport $\mathrm{CO}_{2}$ emissions from the GDP in each EU15 country. The elasticity values are presented by decade in Fig. 7 and the degrees of decoupling by decade in Fig. 8. In the 1990s, weak decoupling was present in Finland, the UK, Germany, Sweden, Denmark and the Netherlands. Transport $\mathrm{CO}_{2}$

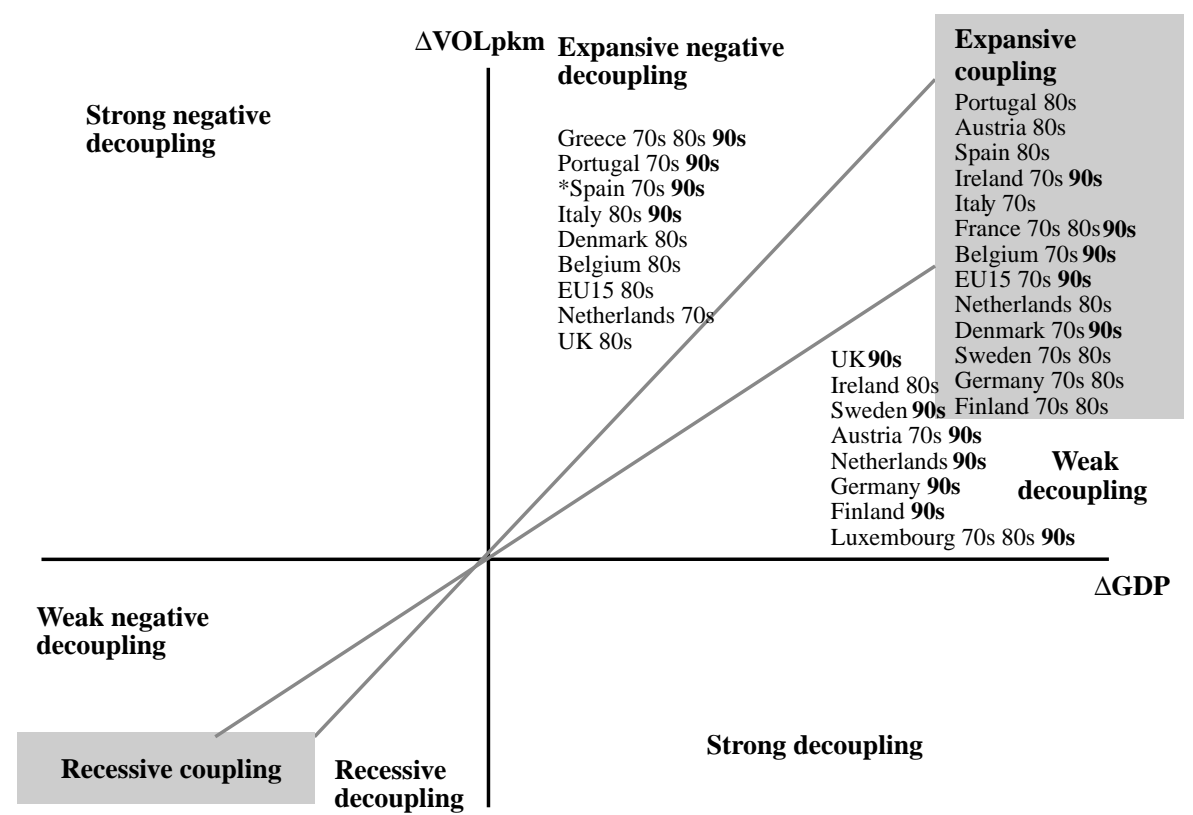

Fig. 4. Decoupling of passenger traffic volume from GDP ${ }_{\mathrm{ppp}}$ in EU15 countries 1970-1980 (70s) 1980-1990 (80s) and 1990-2000 (90s). *Spain 90s contains the years 1991-2001. 


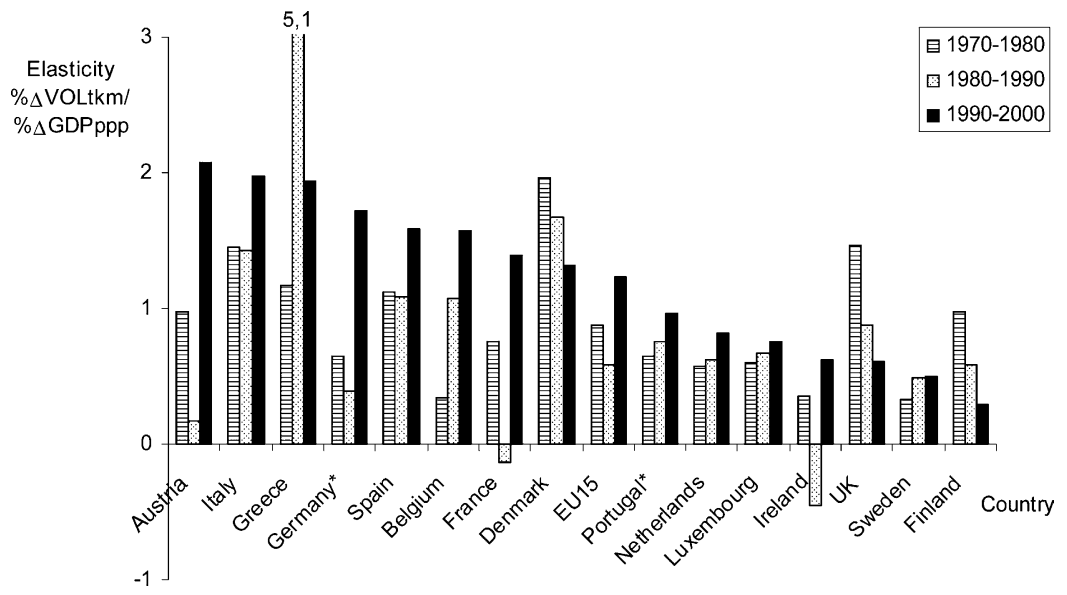

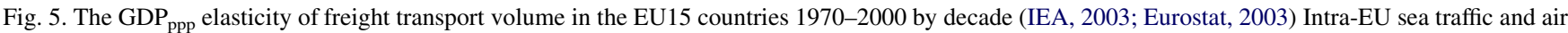
traffic excluded. *The last decade of Germany and Portugal consists of the years 1991-2001.

emissions were expansively coupled to GDP in Belgium, France, Greece, Italy, Ireland, Luxembourg and Austria. Spain and Portugal presented expansive negative decoupling in the 1990s. The Luxembourg data may be distorted because consumers from the neighbour countries fill their tanks in Luxembourg, attracted by lower fuel prices.

\subsection{The case of road traffic in Finland}

Based on the analysis above, weak decoupling of passenger transport, freight transport and transport $\mathrm{CO}_{2}$ emissions from the GDP can be established in three countries in the EU15 in the 1990s: the UK, Sweden and Finland. Next, the Finnish case is analysed in more detail. The focus is, on the one hand, on decoupling of road traffic from GDP, and, on the other hand, on decoupling of road traffic $\mathrm{CO}_{2}$ emissions from road traffic volume. The consistency of $\mathrm{CO}_{2}$ data with the road traffic volume data offers a possibility to analyse all the elasticity values of the Eqs (1)-(3) (see Section 2.1). As only one country is under scrutiny here, it is also easier to make observations based on changes in the trends in addition to linear timescales by decade.

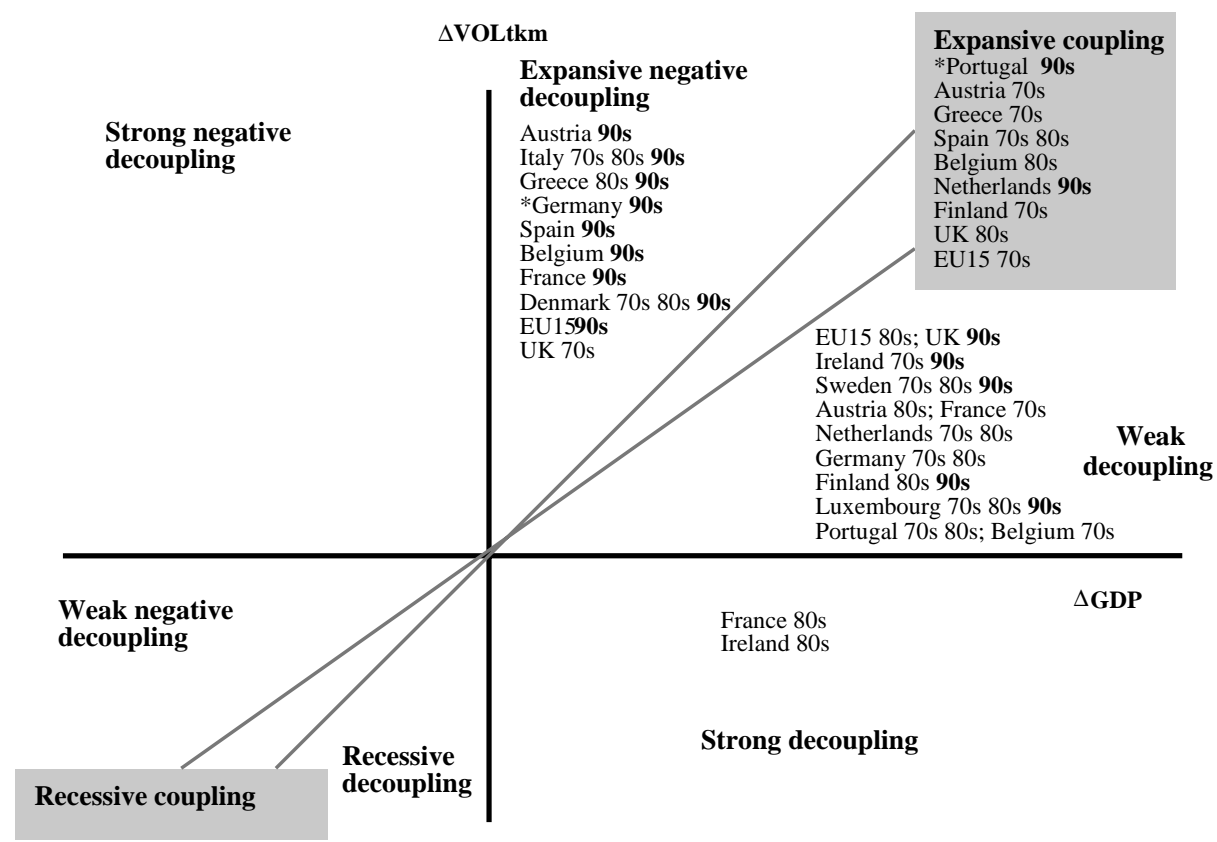

Fig. 6. Decoupling of freight transport volume from GDP ${ }_{\mathrm{ppp}}$ in EU15 countries 1970-1980 (70s) 1980-1990 (80s) and 1990-2000 (90s) *The last decade of Germany and Portugal consists of the years 1991-2001. 


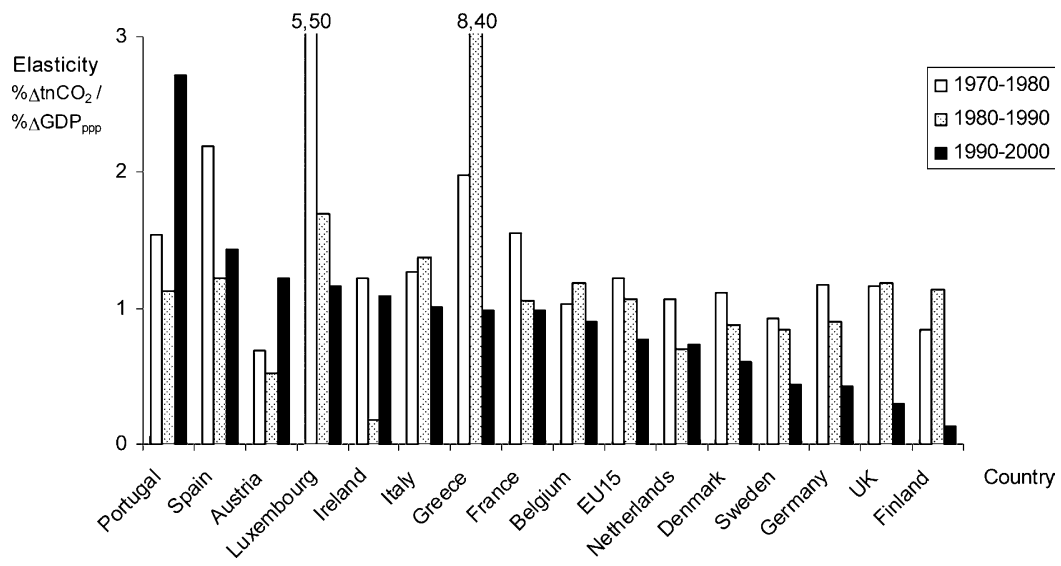

Fig. 7. The $\mathrm{GDP}_{\mathrm{ppp}}$ elasticity of transport $\mathrm{CO}_{2}$ emissions in the EU15 countries $1970-2000$ by decade (IEA, 2003).

Fig. 9 illustrates the data. Following the definitions of Section 1.2 and 1.3, Finland experienced expansive negative decoupling of road traffic volume from GDP and weak decoupling of road traffic $\mathrm{CO}_{2}$ from road traffic volume between 1970 and 1978. After that, there was a period of expansive coupling of all the three variables between 1978 and 1990. The development during the recession between 1990 and 1994 may be characterised as weak negative decoupling, as GDP had negative growth for several years and, in addition, road traffic volume was in slight decrease. Road traffic $\mathrm{CO}_{2}$ and road traffic volume remained recessively coupled. Weak decoupling of all three variables can be detected between 1995 and 2001.

Compared to the Kyoto protocol base year of 1990, the $\mathrm{GDP}_{\text {mer }}$ grew by $24 \%$ in Finland by the year 2001; the road traffic volume grew by $10.8 \%$ and the $\mathrm{CO}_{2}$ emissions from road traffic decreased by $1.3 \%$. In this period, road traffic volume and road traffic $\mathrm{CO}_{2}$ emissions showed strong decoupling. The GDP elasticities by decade for the period between 1970 and 2000 show a clear decline in the 1990s (Fig. 10).

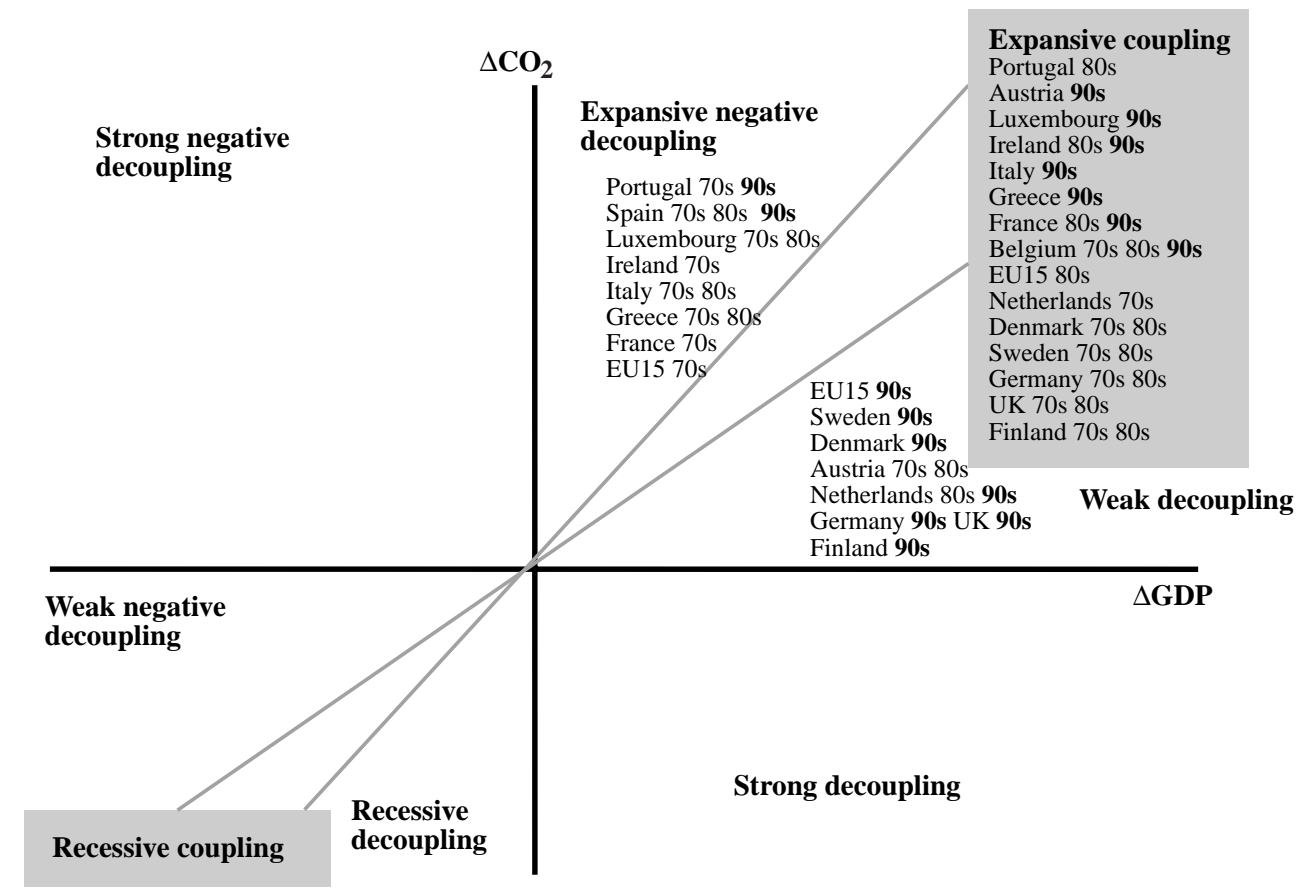

Fig. 8. Decoupling of transport $\mathrm{CO}_{2}$ emissions from $\mathrm{GDP}_{\mathrm{ppp}}$ in EU15 countries 1970-1980 (70s) 1980-1990 (80s) and 1990-2000 (90s). 


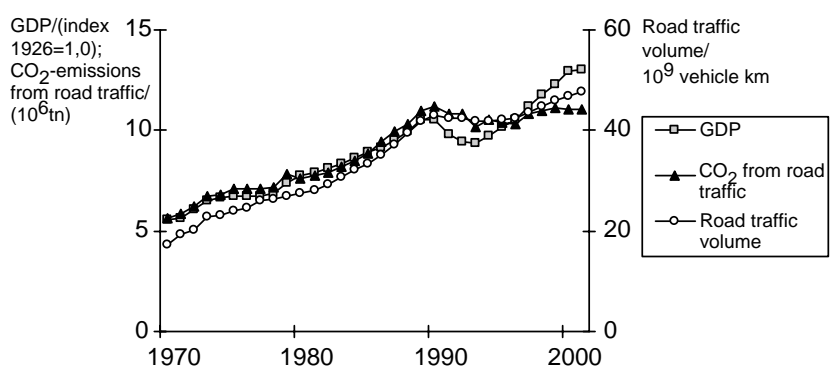

Fig. 9. $\mathrm{GDP}_{\text {mer }}$ in real terms, road traffic volume and the $\mathrm{CO}_{2}$ emissions from road traffic in Finland 1970-2001 (Statistics Finland, 2002a,b; FinnRA, 2002; Mäkelä, 2002).

\section{Discussion}

In the Kyoto Protocol (1997), the EU has committed to the target of reducing total greenhouse gas emissions by 8\% until 2008-2012 from the values of 1990. Finland, belonging to the EU 'bubble', has a more modest $0 \%$ target. No official sectoral targets for transport have been made, and emission reductions within one sector would allow an increase in another. As an exception, Finland has included the emission stabilisation target in the Working Group of Road Transport for road transport $\mathrm{CO}_{2}$ emissions (Ministry of Transport and Communications, 1999).

At the moment, the EU15 countries as a whole seem to have severe problems in achieving the minus $8 \%$ target (Kaivo-oja and Luukkanen, 2004). This view is supported by the IEA (2003) statistics as none of the countries succeeded in achieving any reduction in the transport sector between 1990 and 2001. The total transport $\mathrm{CO}_{2}$ emission growth rates were $43 \%$ in the 1970s; $29 \%$ in the 1980s; and $18 \%$ in the 1990s. Extrapolating the growth rates for 2010 would mean a total growth of some $30 \%$ in transport $\mathrm{CO}_{2}$ emissions between 1990 and 2010. This is hardly consistent with the Kyoto Protocol as the total $\mathrm{CO}_{2}$ emissions of EU15 grew by some $3 \%$ between 1990 and 2001, after a decade of reducing emissions between 1980 and 1990. It is also noteworthy that achieving the Kyoto target itself will

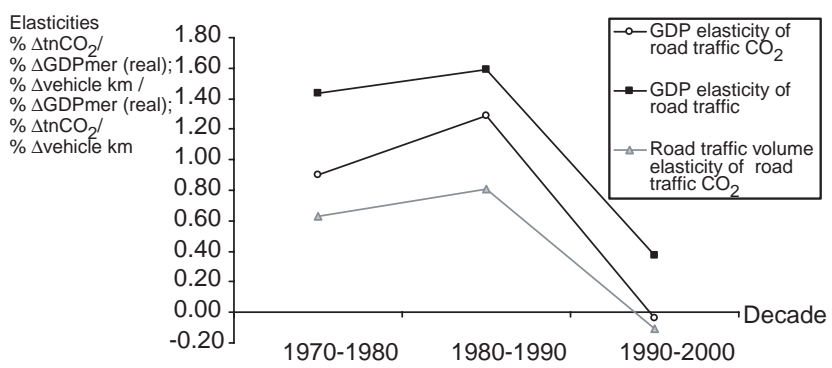

Fig. 10. GDP elasticities of road traffic volume and the $\mathrm{CO}_{2}$ emissions from road traffic, and road traffic volume elasticity of road traffic $\mathrm{CO}_{2}$ emissions by decade in Finland 1970-2000 (calculated from Fig. 9). probably not be enough to stop climate change (IPCC, 1996).

In the latest EU white paper on transport, decoupling is taken as a goal (European Commission, 2001), and some positive development may be observed as well. The EU statistics show a decrease of GDP elasticity of passenger traffic volume in the 1990s, which can be considered a weak signal of a significant change in the future (see Mendonça et al., 2004). Nevertheless, GDP elasticity of freight transport has increased strongly, expressing expansive negative decoupling in the 1990. Indeed, it seems that the EU principle of free movement of people and goods has concerned goods more than people. The EU15 have by no means developed in unison, and weak decoupling of passenger transport, freight transport as well as transport $\mathrm{CO}_{2}$ emissions from the GDP could be seen in the UK, Sweden and Finland in the 1990s.

The statistics show the weak decoupling of road traffic volume from GDP and strong decoupling of the $\mathrm{CO}_{2}$ emissions from road traffic (as well as from GDP) in Finland between 1990 and 2001. At least four hypothetical explanations for the Finnish phenomenon can be put forward. The first two of the presented explanations could be considered optimistic, and the last two pessimistic regarding decoupling. Some empirical evidence is gathered to support each of the hypotheses.

\subsection{Policy for sustainable mobility}

Is Finland a best practice example of policies for sustainable mobility? With an $89 \%$ acquisition tax, cars have been expensive; in addition, fuel prices increased markedly in the 1990s (Eurostat, 2002). Although the fuel price elasticity of road transport has been quite modest in the past (Banister, 1997, 439-440; Hirota et al., 2003), it may be argued that in the end of the 1990s fuel prices entered a level where the elasticity starts to increase (see Fowkes et al., 1998, 40-41; FinnRA, 2000). As both the acquisition and the use of a car are expensive, people might have stopped buying larger cars, thus helping the agreement between ACEA and EU to be fulfilled in practice.

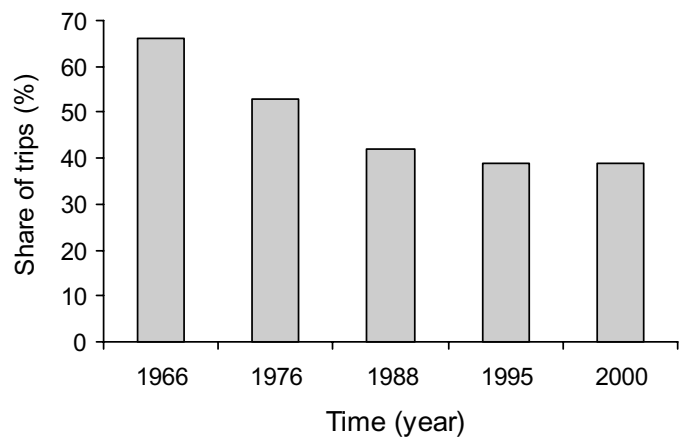

Fig. 11. Public transport share of trips in the Helsinki Metropolitan area in 1966, 1976, 1988, 1995 and 2000 (YTV, 2002, 11). 


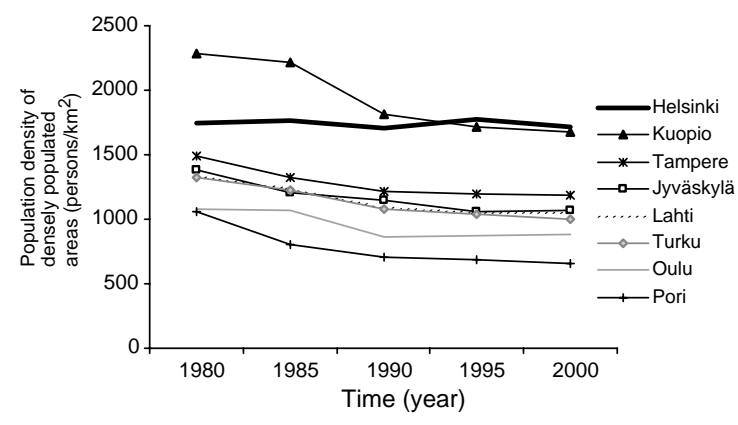

Fig. 12. Population density in densely populated urban areas of over 80000 inhabitants in Finland 1980-2000 (Ristimäki et al., 2003, 173) Densely populated urban areas are defined as functional and physical entities, not by municipality borders (see Ristimäki et al., 2003, p. 190 for more exact definitions).

Governmental funding for new road infrastructure in the early 1990s was decreased clearly while the rail budget was maintained almost even during the recession between 1990 and 1994. There has been a steady increase in soft mode lane kilometres (Neuvonen, 2002) and, for example, the modal share of public transport in the Helsinki Metropolitan area stopped decreasing in the 1990s (Fig. 11). The overall emphasis of high-tech in the Finnish economy, including governmental projects to construct an information society, has brought on the Nokia effect. The high-tech emphasis is essential for immaterialisation.

\subsection{Green urban lifestyle}

Has the urbanisation of Finns familiarised them with public transport? Finland has become urban relatively recently, mostly in the 1960s and 1970s. As the policy of diminishing regional differences was abolished during the recession between 1990 and 1994, Finland experienced another fast pulse of urbanisation. Problematic social impacts resulted from uneven regional development, but the competitiveness of public transport was amended. Restricted parking policy in city centres, together with the raising environmental awareness, may also play a role in the low-growth mobility. Land use planning in the major cities, the Helsinki metropolitan area, Tampere, Turku, Jyväskylä and Oulu, has supported urban infill, although there are still sprawl problems. The population density in urban areas continued to decline in the 1990s, but some changes in the trend could be seen (Fig. 12).

In order to get a driving licence in Finland, one has to attend a driving school of a high cost. As young people use a major proportion of their budget to information and communication technology (ICT) and mobile phone bills, they have less money for driving licence acquisition. When public transport works well, the motivation to save for driving licence is not high. Consequently, in the Helsinki metropolitan area the share of licence holders, regarding both young men and women, is approximately $20 \%$ units lower than elsewhere in the country. There is some evidence of adolescents postponing the acquisition of driving licence in the 1990s, perhaps reflecting a decreased status value of the passenger car (Kokkarinen, 2000, 2001; Häkkänen et al., 2003; Fig. 13). Häkkänen et al. compared these data to Norwegian and Swedish data during the period between 1985 and 2001, concluding that the signal of change is rather weak in Finland, whereas it is clear in Sweden and Norway. However, regarding the longer period between 1978 and 2001 (Fig. 13), a discernible change in the Finnish trend can be suggested as well.

Along with urbanisation, the older generations were left in the countryside. Visiting relatives over long distances has created a large share of traffic, which will, according to

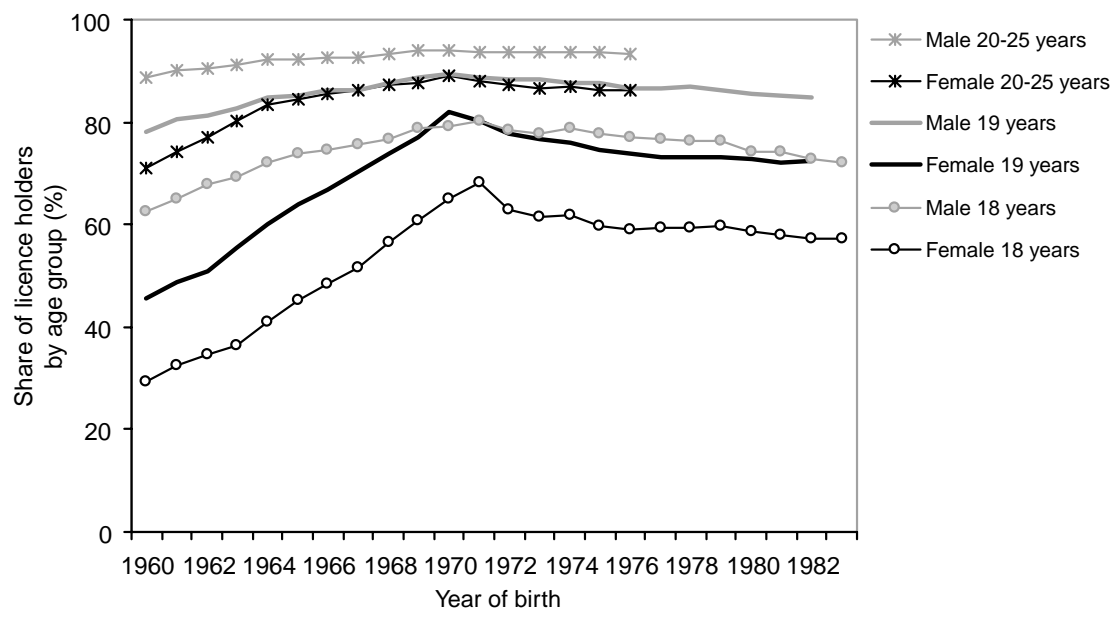

Fig. 13. Cumulative share of driving licence holders by age group in Finland 1978-2001 (calculated from Häkkänen et al., 2003, p. A2) The upper curves are cut as adolescents born in 1977-1983 had not yet reached the age of 25 by 2001. 
some traffic professionals, eventually decrease, as the senior relatives will be deceased (Tapio, 2002b).

\subsection{Increasing income differences}

The third explanation would suggest that the Finnish economy and a group of households still have not recovered from the recession between 1990 and 1994. As the Finnish unemployment rate exceeded $16 \%$ in 1994, thereafter declining slowly to $9,1 \%$ in 2001 (Statistics Finland, 2002c), a consumer segment permanently under the threshold of affording a car was generated.

The income differences have increased rapidly in the 1990s, as the income increase between 1990 and 2000 mainly concerned the richest two deciles, especially capital gain (Finnish Environment, 2000; Kokkarinen, 2001). An indicator of income differences, the Gini coefficient, shows a clear change in the trend, as the income differences were reduced in the 1970s, kept constant in the 1980s and increased again in the 1990s (Fig. 14). Partly this can be explained by change of government composition towards right wing parties and partly by the global competition of high skilled employees, as the 'brain drain' and the fear of relocation of Finnish firms to lower labour cost countries has been considered a problem in Finland. Both factors have resulted in tax reductions favouring middle and high income groups and reductions of revenues for the low income groups.

\subsection{Statistical misinterpretation}

Has international air traffic substituted road traffic with the globalisation of the economy? The last explanation suggests

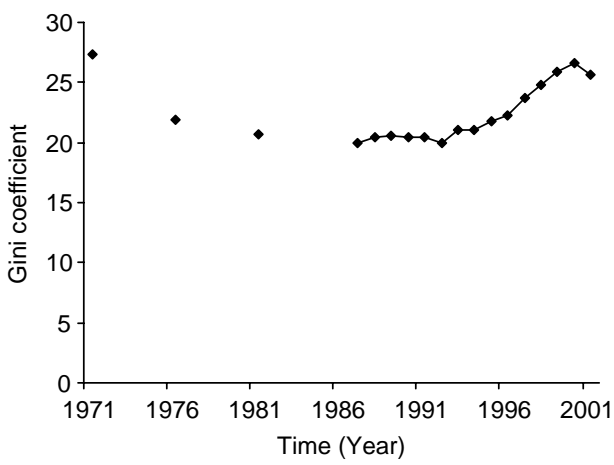

Fig. 14. Disposable income differences in Finland in 1971, 1976, 1981 and 1987-2001 measured by the Gini coefficient (Statistics Finland, 2003) OECD equivalence scale ( 1 for the first adult -0.7 for other adults -0.5 for children) person weights used. There was a slight change in the definition in 1993. The Gini coefficient is defined as $A /(A+B)$ where $A$ is the area between the Lorenz curve (actual cumulative distribution) and the perfect equality line; $B$ is the area between the Lorenz curve and perfect inequality line. If one household would have all the income, the Gini coefficient value would be 1 (equals 100 in the figure), if there would be an equal share of income for all households the value would be zero. The Gini coefficient can be used also for other distributions than income. that the evidence of decoupling could be distorted if people have started to use their limited travel time budget to faster travel modes (see Schafer, 1998; Schafer and Victor, 2000). The increase in domestic air traffic does not explain the saturation of road traffic $\mathrm{CO}_{2}$ emissions sufficiently, as air traffic increased only from 1.0 to 1.3 billion passenger $\mathrm{km}$ between 1990 and 2001, while road traffic increased from 51.2 to 57.0 billion passenger $\mathrm{km}$. By contrast, the increase in international flights could prove to be a plausible explanation for the saturation (FinnRA, 2004).

However, it is not air traffic that accounted for most of the increase in traffic $\mathrm{CO}_{2}$ emissions in Finland between 1990 and 2001, but the slower waterborne modes. The total $\mathrm{CO}_{2}$ emissions of transport increased by $8.4 \%$, or by 1.24 million tonnes between 1990 and 2001, of which waterborne modes accounted for 0.81 million tonnes (Mäkelä, 2002). The high share of $\mathrm{CO}_{2}$ emissions from waterborne modes can be explained by a $65 \%$ increase in export of industrial products, $29 \%$ increase in import, and an over 10-fold increase in tourist trips to Estonia after the collapse of the Iron Curtain (FMA, 2004a,b). ${ }^{3}$ Due to statistical problems, the whole picture of international flights remains unclear. Unfortunately, the major national travel surveys in 1992 and 1998/ 1999 were conducted using incomparable methods, which prohibit the verification of this suggestion.

\subsection{Policy conclusions}

Decoupling of traffic volume from the GDP and decoupling of transport $\mathrm{CO}_{2}$ emissions from transport volume have risen in the transport policy agenda. Observing the development in the last three decades in the EU15 countries, these targets may seem overly demanding as no decoupling of traffic volumes from economic growth can be found in the aggregate EU15 data. However, the transport $\mathrm{CO}_{2}$ elasticity of GDP has come down steadily even if the target has been considered important only for the last decade.

Some fatalistic aspects have been presented stating that there is little if anything to be done to the connection between GDP and traffic volume, which is supposedly a determined invariance (IPCC, 1996, 2001; Dargay and Gately, 1999; Schafer and Victor, 2000). This approach has been criticised of being an example of 'Comtean positivism' (Tapio, 1996; Tapio and Hietanen, 2002), 'predict and provide' approach (Owens, 1995; Banister, 1999; Goodwin, 1999) and 'determinism' (Höjer and Mattsson, 2000).

The French philosopher and the 'father of sociology' Comte $(1974$, p. $410-437,459-473)$ stated in the mid-19th century, that the task of social science is to find out the laws of societal development the same way as a natural scientist finds out the laws of nature. Thus decision-makers may adapt to the natural development and avoid making wrong decisions.

\footnotetext{
${ }^{3}$ The relative share of international passenger traffic to Estonia increased from 5.1 to $38.7 \%$ of total departures (FMA, 2004b).
} 
The philosophical problem of the fatalistic argument is that if we consider all past and current invariances also invariant in the future, there is no room for any policies whatsoever, as the decisions would also have been predetermined (see eg Popper, 1960). Comte was aware of the argument and he responded, that there are small things, which decision-makers may decide upon, but the general societal development is beyond decision-making.

The Comtean argument is implicitly included in many traffic forecasts, as no decoupling is usually expected nor speculated upon (Tapio and Hietanen, 2002; Banister and Stead, 2002). Some policy measures, such as fuel prices, may be included in the analyses, but the general theory of increasing GDP, resulting in equally increasing mobility, has seldom been questioned. This may be fine as an academic exercise, but, as a basis for transport policy making, the forecasts tend to have a self-fulfilling nature: A prediction is made that traffic volume will grow following GDP growth. Model calculations show that the forecast traffic volume will congest the current road network. Therefore, larger roads must be provided. As a result, road capacity increases and road traffic increases (see van Vught, 1987; Owens, 1995; Tapio, 1996; Goodwin, 1997; Mogridge, 1997).

'Predict and provide' should merely be changed to the 'what...if' principle, according to which several wider policy scenarios would be addressed (Schwarz et al., 1982). An example of the 'what...if' principle are the backcasting exercises in the transport field (Höjer and Mattsson, 2000; Banister et al., 2000). The critique points to the need for change, and there are indeed signs of governmental will for change at least in Sweden, the UK and Finland (Tengström, 1999; Banister, 1999; Goodwin, 1999; Tapio and Hietanen, 2002), the three EU countries presenting decoupling of both passenger and freight transport as well as transport $\mathrm{CO}_{2}$ emissions in the 1990s. As for Finland, a question can be put forward whether it is changing its course from a socially and economically sustainable but ecologically unsustainable development towards economically and ecologically sustainable development by forgetting the socio-cultural sustainability.

\section{Acknowledgements}

The article is a contribution of the project Spaces of Nature and Culture in Transport Policy (TRAPO) funded by the Academy of Finland. Roberto Camagni, Roberta Capello, Dario Musolino, John Preston and Jarmo Vehmas gave inspiring comments to the manuscript.

\section{Appendix A. Data used in decoupling analyses of the EU15}

$\mathrm{GDP}_{\mathrm{ppp}}$, passenger transport volume, freight transport volume and the $\mathrm{CO}_{2}$ emissions of transport in the EU15 countries ${ }^{\mathrm{a}}$ 1970-2000 (Eurostat, 2003; IEA, 2003) .

\begin{tabular}{|c|c|c|c|c|c|c|c|c|c|c|c|c|c|c|c|c|}
\hline & A & B & DK & FIN & $\mathrm{F}$ & $\mathrm{D}^{\mathrm{c}}$ & EL & IRL & I & $\mathrm{L}$ & NL & $\mathrm{P}^{\mathrm{c}}$ & $E^{d}$ & $\mathrm{~S}$ & UK & EU15 ${ }^{\mathrm{e}}$ \\
\hline \multicolumn{17}{|c|}{$G D P_{p p p}\left(10^{9} U S \$_{1995}\right)$} \\
\hline 1970 & 86 & 121 & 77 & 51 & 644 & 958 & 66 & 23 & 607 & 5.4 & 178 & 57 & 290 & 117 & 639 & 3929 \\
\hline 1980 & 123 & 168 & 93 & 73 & 892 & 1258 & 118 & 36 & 865 & 7.0 & 237 & 91 & 415 & 142 & 775 & 5293 \\
\hline 1990 & 156 & 205 & 109 & 100 & 1138 & 1580 & 126 & 52 & 1082 & 11.3 & 296 & 125 & 554 & 176 & 1008 & 6718 \\
\hline 2000 & 198 & 254 & 137 & 124 & 1369 & 1911 & 159 & 104 & 1265 & 19.0 & 394 & 164 & 720 & 214 & 1269 & 8300 \\
\hline 2001 & 199 & 256 & 138 & 125 & 1395 & 1922 & 165 & 110 & 1287 & 19.2 & 399 & 167 & 739 & 216 & 1293 & 8431 \\
\hline \multicolumn{17}{|c|}{ Passenger traffic $\left(10^{9} \mathrm{pkm}\right)^{\mathrm{f}}$} \\
\hline 1970 & 52.6 & 60.6 & 43.6 & 35.8 & 405 & 561 & 24.9 & 15.5 & 328 & 3.28 & 92.4 & 29.6 & 120 & 72.8 & 406 & 2249 \\
\hline 1980 & 69.8 & 84.0 & 51.8 & 49.9 & 582 & 706 & 54.2 & 24.1 & 488 & 3.95 & 134.2 & 51.7 & 205 & 90.2 & 499 & 3092 \\
\hline 1990 & 86.1 & 111.5 & 65.9 & 67.9 & 733 & 862 & 87.9 & 25.4 & 730 & 5.44 & 168.9 & 68.2 & 270 & 113.1 & 708 & 4104 \\
\hline 2000 & 99.5 & 135.2 & 80.6 & 73.9 & 864 & 921 & 142.4 & 46.3 & 906 & 6.87 & 192.7 & 118.4 & 450 & 127.8 & 764 & 4929 \\
\hline 2001 & 99.9 & 137.2 & 80.4 & 75.0 & 891 & 911 & 147.3 & 48.6 & 910 & 7.03 & 192.8 & 121.7 & 459 & 128.5 & 776 & 4986 \\
\hline \multicolumn{17}{|c|}{ Freight transport $\left(10^{9} \mathrm{tkm}\right)^{\mathrm{g}}$} \\
\hline 1970 & 23.8 & 28.5 & 10.5 & 22.6 & 223 & 297 & 8.0 & 4.9 & 110 & 1.34 & 54.7 & 8.7 & 63.2 & 45.1 & 132 & 1034 \\
\hline 1980 & 33.6 & 32.4 & 14.8 & 32.0 & 289 & 357 & 13.3 & 5.9 & 178 & 1.57 & 65.2 & 12.1 & 93.6 & 48.3 & 173 & 1349 \\
\hline 1990 & 35.1 & 40.0 & 19.0 & 38.7 & 278 & 392 & 18.1 & 4.7 & 242 & 2.23 & 75.4 & 15.5 & 127.8 & 53.9 & 219 & 1562 \\
\hline 2000 & 54.6 & 55.1 & 25.4 & 41.4 & 357 & 505 & 27.4 & 7.7 & 323 & 3.38 & 95.9 & 17.3 & 188.6 & 59.6 & 254 & 2015 \\
\hline 2001 & 56.5 & 56.3 & 25.5 & 40.6 & 358 & 509 & 28.8 & 8.2 & 318 & 3.42 & 96.5 & 17.5 & 200.4 & 57.1 & 245 & 2021 \\
\hline \multicolumn{17}{|c|}{ Transport $\mathrm{CO}_{2}\left(10^{6} t\right)^{\mathrm{h}}$} \\
\hline 1970 & 9.2 & 11.5 & 7.3 & 6.2 & 56.2 & 95.2 & 4.5 & 2.7 & 46.6 & 0.49 & 16.5 & 3.6 & 23.5 & 14.2 & 72.7 & 392 \\
\hline 1980 & 11.9 & 16.1 & 9.1 & 8.4 & 89.7 & 130 & 9.6 & 4.6 & 71.7 & 1.29 & 22.4 & 6.9 & 45.5 & 17.0 & 90.5 & 558 \\
\hline 1990 & 13.6 & 20.4 & 10.4 & 11.8 & 116 & 160 & 15.4 & 5.0 & 96.5 & 2.65 & 26.4 & 9.9 & 64.1 & 20.4 & 123 & 719 \\
\hline 2000 & 18.0 & 24.7 & 12.0 & 12.2 & 139 & 174 & 19.3 & 10.4 & 113 & 4.74 & 32.8 & 18.2 & 91.8 & 22.3 & 132 & 848 \\
\hline 2001 & 19.3 & 25.5 & 11.3 & 12.5 & 142 & 170 & 20.0 & 10.9 & 115 & 5.00 & 33.2 & 18.3 & 95.6 & 21.7 & 127 & 852 \\
\hline
\end{tabular}




\begin{tabular}{|c|c|c|c|c|c|c|c|c|c|c|c|c|c|c|c|c|}
\hline & A & B & DK & FIN & $\mathrm{F}$ & $\mathrm{D}^{\mathrm{c}}$ & EL & IRL & I & $\mathrm{L}$ & NL & $\mathrm{P}^{\mathrm{c}}$ & $\mathrm{E}^{\mathrm{d}}$ & S & UK & $\mathrm{EU} 15^{\mathrm{e}}$ \\
\hline \multicolumn{17}{|c|}{$\operatorname{Road~} \mathrm{CO}_{2}\left(10^{6} t\right)$} \\
\hline 1970 & 7.7 & 10.1 & 5.9 & 5.3 & 51.2 & 78.3 & 3.3 & 2.4 & 41.0 & 0.44 & 12.6 & 2.4 & 15.4 & 11.8 & 59.7 & 307 \\
\hline 1980 & 11.2 & 14.9 & 7.0 & 7.6 & 82.7 & 118 & 6.9 & 4.4 & 66.5 & 1.25 & 20.2 & 5.8 & 31.5 & 15.2 & 77.5 & 471 \\
\hline 1990 & 13.0 & 19.6 & 9.3 & 11.0 & 110 & 151 & 11.7 & 4.7 & 93.1 & 2.64 & 25.1 & 9.2 & 53.7 & 18.1 & 109 & 641 \\
\hline 2000 & 17.1 & 23.7 & 11.1 & 11.1 & 130 & 170 & 16.0 & 10.1 & 111 & 4.66 & 31.3 & 17.1 & 80.0 & 20.1 & 117 & 770 \\
\hline 2001 & 18.3 & 24.5 & 10.5 & 11.4 & 132 & 166 & 16.3 & 10.6 & 113 & 4.96 & 31.8 & 17.3 & 84.0 & 20.1 & 117 & 778 \\
\hline
\end{tabular}

${ }^{\text {a }} \mathrm{A}=$ Austria, $\mathrm{B}=$ Belgium, $\mathrm{DK}=$ Denmark, FIN = Finland, =France, $\mathrm{D}=$ Germany (estimates of Eastern Germany included for the whole period), EL $=$ Greece, IRL = Ireland, $\mathrm{I}=\mathrm{Italy} ; \mathrm{L}=$ Luxembourg, $\mathrm{NL}=$ Netherlands, $\mathrm{P}=$ Portugal, $\mathrm{E}=$ Spain, $\mathrm{S}=$ Sweden, UK=United Kingdom, EU15=All the 15 countries participating in the European Union 1995-2004.

b The data include numerous changes in transport statistics (see Eurostat, 2003 for details).

${ }^{\mathrm{c}}$ For the last decade of GDP elasticity of freight transport in Germany and Portugal, the values of $1991\left(400 \times 10^{9}\right.$ tkm and $13.8 \times 10^{9}$ tkm, respectively) and 2001 were used.

${ }^{\mathrm{d}}$ For the last decade of GDP elasticity of passenger transport in Spain, the values of $1991\left(311 \times 10^{9} \mathrm{pkm}\right.$ including assumed 12,75 of powered twowheelers) and 2001 were used.

${ }^{\mathrm{e}}$ For the total EU15 area, GDP elasticities of freight transport were also calculated using additional data of intra-EU sea transport, the total freight transport volume values being 1506 in 1970; 2131 in 1980; 2485 in 1990; and 3285 in 2000.

${ }^{f}$ Passenger transport includes passenger cars, buses, coaches, powered two-wheelers, tram, metro, railway, domestic and intra-EU flights. Air traffic values for 1970 and 1980 were extrapolated from the values of 1990 and 2000 assuming a constant relative growth rate of air traffic by decade. These were: A $77 \%$, B 119\%, DK 78\%, FIN 53\%, F 51\%, D 83\%, EL 79\%, IRL 161\%, I 89\%; L 68\%, NL 135\%, P 68\%, E 95\%, S 42\%, UK 78\% and EU15 80\%. Maritime transport, walking, cycling and other soft modes are excluded. Air traffic between EU and non-EU countries is excluded as well.

${ }^{\mathrm{g}}$ Freight transport includes national and international road haulage, railways, inland waterways, pipelines (oil) and domestic sea transport. Intra-EU sea transport and pipeline transport other than oil (e.g. water and gas) are excluded. Air transport is excluded as it does not contribute much to tkm.

${ }^{\mathrm{h}}$ International maritime and aviation emissions (also intra-EU) excluded.

\section{References}

Acutt, M.Z., Dodgson, J.S., 1998. Transport and global warming: modelling the impacts of alternative policies, in: Banister, D. (Ed.), Transport Policy and the Environment. E \& FN Spon, London, pp. 20-37.

Arrow, K., Bolin, B., Costanza, R., Dasgupta, P., Folke, C., Holling, C.S., Jansson, B.-O., Levin, S., Mäler, K.-G., Perrings, C., Pimentel, D., 1995. Economic growth, carrying capacity, and the environment. Ecological Economics 15 (2), 91-95.

Banister, D., 1997. Reducing the need to travel. Environment and Planning B: Planning and Design 24 (3), 437-449.

Banister, D., 1999. Planning more to travel less: land use and transport. TPR 70 (3), 313-338.

Banister, D., Stead, D., 2002. Reducing transport intensity. European Journal of Transport Infrastructure Research 2 (3/4), 161-178.

Banister, D., Stead, D., Steen, P., Åkerman, J., Dreborg, K., Nijkamp, P., Schleicher-Tappeser, R., 2000. European Transport Policy and Sustainable Mobility. Spon, London.

Canas, Â., Ferrão, P., Conceição, P., 2003. A new environmental Kuznets curve? Relationship between direct material input and income per capita: evidence from industrialised countries. Ecological Economics 46 (2), 217-229.

CEGTE, 2000. Measures that simultaneously address climate change and other environmental or other aspects of sustainability, Commission Expert Group on Transport and Environment, Working Group II, 13 September 2000 2000. Downloaded from http://europa.eu.int/comm/ environment/trans/reportwg2.pdf.

A. Comte., (1974, orig 1855) The Positive Philosophy, translated and edited by Martineau, H. AMS Press, New York.

Dargay, J., Gately, D., 1999. Income's effect on car and vehicle ownership, worldwide: 1960-2015. Transportation Research Part A 33 (2), 101138.

de Bruyn, S., 2002. Dematerialization and rematerialization as two recurring phenomena of industrial ecology, in: Ayres, R.U., Ayres, L.W. (Eds.), A Handbook of Industrial Ecology. Edward Elgar, Cheltenham, pp. 209-222. de Bruyn, S.M., van den Bergh, J.C.J.M., Opschoor, J.B., 1998. Economic growth and emissions: reconsidering the empirical basis of environmental Kuznets curves. Ecological Economics 25 (2), 161-175.

European Commission, 2001. White Paper-European Transport Policy for 2010: Time to Decide. European Communities, Luxembourg.

Eurostat, 1999. EU Transport in Figures 1998. Statistical Pocket Book 1999. DG VII, Eurostat.

Eurostat, 2002. Energy and Transport in Figures 2002. Downloaded at http://europa.eu.int/comm/energy_transport/etif/environment/emissions_sector_graph.gif.

Eurostat, 2003. Energy and Transport in Figures, European Commission 2003. Downloaded at http://europa.eu.int/comm/dgs/energy_transport/ figures/pocketbook/doc/etif_2003.pdf.

Finnish Environment Institute, 2000. Finland's Indicators for Sustainable Development: Income Level Differences 2000. Downloaded at http:// www.vyh.fi/eng/environ/sustdev/indicat/tulot.htm.

FinnRA, 2000. Polttoaineen hinnannousun vaikutus autonkäyttöön maaliselokuussa 2000, Publications of Finnish Road Administration 56/2000, Helsinki 2000. [The effect of fuel price increase on car use in MarchAugust 2000, in Finnish.].

FinnRA, 2002. Koko maan liikennesuorite autolajeittain vuosina 1970 2000. Finnish Road Administration. Downloaded at http://www.tieh.fi/ aikas/liiks.htm. [Road traffic volume by mode in Finland from 19702000.].

FinnRA, 2004. Kotimaan henkilöliikenne vuosina 1960-2003. Finnish Road Administration. Downloaded at http://www.tiehallinto.fi/pls/ wwwedit/docs/4827.PDF. [Domestic passenger traffic from 19602003.].

FMA, 2004a. Ulkomaan merikuljetukset tavararyhmittäin vuosina 19802003. Finnish Maritime Administration. Downloaded at http://www. fma.fi/palvelut/tilastot $/ \mathrm{mlt} / \mathrm{mlt}$ _ta_tavararyhmat.htm. [International maritime transport by product group from 1980-2003, in Finnish and Swedish.].

FMA, 2004b. Matkustajaliikenne Suomen ja ulkomaiden välillä maittain 1980-2003. Finnish Maritime Administration. Downloaded at http:// www.fma.fi/palvelut/tilastot/mlt/mlt_ma_maittain.htm. [International passenger traffic by country from 1980-2003, in Finnish and Swedish.]. 
Focacci, A., 2003. Empirical evidence in the analysis of the environmental and energy policies of a series of industrialised nations, during the period 1960-1997, using widely employed macroeconomic indicators. Energy Policy 31 (4), 333352.

Fowkes, A.S., May, A.D., Nash, C.A., Siu, Y.L., Rees, P.H., 1998. Forecasting road traffic growth, in: Banister, D. (Ed.), Transport Policy and the Environment. E \& FN Spon, London, pp. 38-49.

Goodwin, P., 1997. Doomsday postponed. Transport Policy 4 (1), 1-3.

Goodwin, P., 1999. Transformation of transport policy in Great Britain. Transportation Research Part A 33 (7-8), 655-669.

Häkkänen, H., Britschgi, V., Sirkiä, A., Kanner, H., 2003. Nuorten aikomus hankkia ajokortti, second ed., VTT tiedotteita-Research Notes 2075 2003 Espoo. [Willingness to obtain a driving licence among Finnish adolescents, in Finnish, Abstract in English.].

Hinterberger, F., Schmidt-Bleek, F., 1999. Dematerialization, MIPS and Factor 10: physical sustainability indicators as a social device. Ecological Economics 29 (1), 53-56.

Hirota, K., Poot, J., Minato, K. (2003) 'Do policy incentives affect the environmental impact of private car use? Evidence from a sample of large cities', Paper presented at "43rd Congress of the European Regional Science Association-Peripheries, Centres and Spatial Development in the New Europe", 27-30 August 2003, Jyväskylä, Finland. CD-ROM.

Hiscock, R., Macintyre, S., Kearns, A., Ellaway, A., 2002. Means of transport and ontological security: do cars provide psycho-social benefits to their users?. Transportation Research Part D 7 (2), 119-135.

Höjer, M., Mattsson, L.-G., 2000. Determinism and backcasting in future studies. Futures 32 (7), 613-634.

IEA, 2000. The Road from Kyoto: Current $\mathrm{CO}_{2}$ and Transport Policies in the IEA, International Energy Agency. IEA Publications 9, Paris.

IEA, 2003. $\mathrm{CO}_{2}$ emissions from fuel combustion 1971-2001, 2003 ed. International Energy Agency. CD-ROM.

IPCC, 1996. Climate change 1995: Impacts, Adaptations and Mitigation of Climate Change: Scientific-Technical Analyses, Contribution of Working Group II to the Second Assesment Report of the Intergovernmental Panel on Climate Change. Cambridge University Press, New York.

IPCC, 2001. Climate Change 2001: Mitigation, Contribution of Working Group III to the Third Assessment Report of the Intergovernmental Panel on Climate Change. Cambridge University Press, Cambridge.

Jänicke, M., 1988. Ökologische Modernisierung, Optionen und Restriktionen präventiver Umweltpolitik, in: Simonis, U.E. (Ed.), Präventive Umweltpolitik. Campus, Frankfurt am Main, pp. 13-26.

Jensen, M., 1999. Passion and heart in transport—a sociological analysis on transport behaviour. Transport Policy 6 (1), 19-33.

Kaivo-oja, J., Haukioja, T., 2002. Kestävä kehitys ja tietoyhteiskunta: Kriittiset ulottuvuudet, in: Kamppinen, M., Kuusi, O., Söderlund, S. (Eds.), Tulevaisuudentutkimus. Perusteet ja sovelluksia. SKS, Helsinki, pp. 483-515. [Sustainable development and the information society: Critical dimensions, in Finnish.].

Kaivo-oja, J., Luukkanen, J., 2004. The European Union balancing between $\mathrm{CO}_{2}$ reduction commitments and growth policies: decomposition analyses. Energy Policy 32 (13), 1511-1530.

Kokkarinen, V., 2000. Ajokorttien määrän kehitys Suomessa 1980-1999. Tulevaisuuden näkymiä 2000 (1), 5-11. Downloaded at http://www. tiehallinto.fi/tn/tnpdf/tn_100i.pdf. [The development of the number of driving licences in Finland in 1980-1999, in Finnish.].

Kokkarinen, V., 2001. Ennusteseuranta. Tieliikenne-ennusteen 1997-2030 toteutuma-tarkastelu. Tulevaisuuden näkymiä 2001 (2), 5-19. Downloaded at http://www.tiehallinto.fi/tn/tnpdf/tn_201i.pdf. [Monitoring traffic forecast for 1997-2030, in Finnish.].

Kriström, B., Lundgren, T. (2005) Swedish $\mathrm{CO}_{2}$-emissions 1900-2010: an exploratory note. Energy Policy 33 (9), 1223-1230.

Kuznets, S., 1955. Economic growth and income inequality. The American Economic Review 45 (1), 1-28.
Kyoto Protocol to the United Nations Framework Convention on Climate Change (1997), Downloaded at http://unfccc.int/resource/docs/convkp/ kpeng.pdf.

Lampinen, R., 1998. Tieliikenne ja ympäristö-tilannekatsaus. Tulevaisuuden näkymiä 1998 (4), 5-11. Downloaded at http://www.tiehallinto. fi/tn/tn498/tn498i.pdf. [Road traffic and the environment-the current state, in Finnish.].

Mäkelä, K., 2002. Suomen liikenteen hiilidioksidipäästöt, LIPASTO inventory of the traffic emissions, Technical Research Centre Finland (VTT) 2002. Downloaded at http://www.vtt.fi/rte/projects/lipasto/ kehco2.htm. [The carbon dioxide emissions from traffic in Finland.].

Mendonça, S., Cunha, M.P., Kaivo-oja, J., Ruff, F., 2004. Wild cards, weak signals and organisational improvisation. Futures 36 (2), 201-218.

Ministry of Transport and Communications, 1999. Toimenpiteet tieliikenteen hiilidioksidipäästöjen vähentämiseksi, Publications of the Ministry of Transport and Communications 16/99, Edita, Helsinki 1999. [Measures to decrease carbon dioxide emissions of road trafficPublication of the Working Goup of $\mathrm{CO}_{2}$ Emissions, in Finnish, Abstract in English.].

Mogridge, M., 1997. The self-defeating nature of urban road capacity policy: a review of theories, disputes and available evidence. Transport Policy 4 (1), 5-23.

Mokhtarian, P.L., Salomon, I., 2001. How derived is the demand for travel? Some conceptual and measurement considerations. Transportation Research Part A 35 (8), 695-719.

Neuvonen, S. (2002) 'Kevyen liikenteen käyttöön vaikuttavat tekijät', Department of Limnology and Environmental Protection, University of Helsinki, Downloaded at http://ethesis.helsinki.fi/julkaisut/maa/limno/ $\mathrm{pg} /$ neuvonen/, Master's thesis.

Nijkamp, P., Rienstra, S.A., Vleugel, J.M., 1998. Transportation Planning and the Future. Wiley, Chichester.

Owens, S., 1995. From 'predict and provide' to 'predict and prevent'? pricing and planning in transport policy. Transport Policy 2 (1), 43-49.

Peake, S., 1994. Transport in Transition: Lessons from the History of Energy. Earthscan, London.

Popper, K., 1960. The Poverty of Historicism. Routledge \& Kegan Paul, London.

Ristimäki, M., Oinonen, K., Pitkäranta, H., Harju, K., 2003. Kaupunkiseutujen väestönmuutos ja alueellinen kasvu, The Finnish Environment 657, Ministry of the Environment Finland, Helsinki 2003. [Population changes in urban regions and urban growth, in Finnish, Abstract in English on p. 196.].

Schafer, A., 1998. The global demand for motorized mobility. Transportation Research Part A 32 (6), 455-477.

Schafer, A., Victor, D.G., 2000. The future mobility of the world population. Transportation Research Part A 34 (3), 171-205.

Schmidt-Bleek, F. (2000) Luonnon uusi laskuoppi, Gaudeamus, Helsinki. [Finnish translation of two books: Wieviel Umwelt braucht der Mensch? MIPS-das Mass für ökologisches Wirtschaften (orig. 1994) and Das MIPS-Konzept. Weniger Naturverbrauch-mehr Lebensqualität durch Faktor 10 (orig. 1998).]

Schwarz, B., Svedin, U., Wittrock, B., 1982. Methods in Futures Studies: Problems and Applications. Westview Press, Boulder.

Seppälä, T., Haukioja, T., Kaivo-oja, J., 2001. The EKC Hypothesis does not hold for direct material flows. An environmental Kuznets curve hypothesis tests for direct material flows in 5 industrial countries. Population and Environment. A Journal of Interdisciplinary Studies 23 (2), 217-238.

Statistics Finland, 2002a. 'Volyymi-indeksit 1860-1995'. Downloaded at http://www.stat.fi/tk/to/sarjat.html. [Volume Indices 1860-1999 (of GDP of Finland).]

Statistics Finland, 2002b. Finland in Figures: National Accounts 2002. Downloaded at http://www.stat.fi/tk/tp/tasku/taskue_kansantalous. html.

Statistics Finland, 2002c. Työmarkkinat 2002. Downloaded at http://www. stat.fi/tk/tp/tasku/taskus_tyoelama.html ['Labour market', in Finnish.]. 
Statistics Finland, 2003. Distribution of equivalent household income in Finland 1966-2001-Gini coefficients 2003. Downloaded at http:// www.stat.fi/tk/el/tulo/gini.html.

Stead, D., 2001. Transport intensity in Europe, indicators and trends. Transport Policy 8 (1), 29-46.

Steg, L., Geurs, K., Ras, M., 2001. The effects of motivational factors on car use: a multidisciplinary modelling approach. Transportation Research Part A 35 (9), 789-806.

Tapio, P., 1996. From technocracy to participation? Positivist, realist and pragmatist paradigms applied to traffic and environmental policy futures research. Futures 28 (5), 453-470.

Tapio, P. (2002a), The Limits to Traffic Volume Growth, The Content and Procedure of Administrative Futures Studies on Finnish Transport $\mathrm{CO}_{2}$ Policy, Acta Futura Fennica 8, Finnish Society for Futures Studies \& Finland Futures Research Centre, Turku, Doctorate thesis. Summary (148 p.) available at http://ethesis.helsinki.fi/julkaisut/maa/limno/vk/ tapio.

Tapio, P., 2002b. Climate and traffic: prospects for Finland. Global Environmental Change 12 (1), 53-68.

Tapio, P., Hietanen, O., 2002. Epistemology and public policy: using a new typology to analyse the paradigm shift in Finnish transport futures studies. Futures 34 (7), 597-620.

Tengström, E., 1999. Towards Environmental Sustainability? A Comparative Study of Danish, Dutch and Swedish Transport Policies in a European Context. Ashgate, Aldershot.
TERM, 2002. Paving the Way to EU Enlargement. Indicators of Transport and Environment Integration. European Environment Agency (EEA), Copenhagen.

Todaro, M.P., 1994. Economic Development, fifth ed. Longman, New York.

Van den Brink, R.M.M., Van Wee, B., 2001. Why has car-fleet specific fuel consumption not shown any decrease since 1990? Quantitative analysis of Dutch passenger car-fleet specific fuel consumption. Transportation Research Part D 6 (2), 75-93.

van Vught, F.A., 1987. Pitfalls of forecasting. Fundamental problems for the methodology of forecasting from the philosophy of science. Futures 19 (2), 184-196.

Vehmas, J., Malaska, P., Luukkanen, J., Kaivo-oja, J., Hietanen, O., Vinnari, M. \& Ilvonen, J. (2003) Europe in the global battle of sustainability: Rebound strikes back?-Advanced Sustainability Analysis, Publications of the Turku School of Economics and Business Administration, Series Discussion and Working Papers 7:2003, Turku

YTV, 2002. Pääkaupunkiseudun liikennejärjestelmäsuunnitelman vaikutusten arviointi, Pääkaupunkiseudun julkaisusarja B 2002:10. Helsinki Metropolitan Area Council (YTV), Helsinki. Downloaded from www. ytv.fi/liikenne/julk/va.html [Impact Assessment of the Transport System Plan of the Helsinki Metropolitan Area, in Finnish, Abstract in English on p. 4.]. 